NAMA : WAHYU RAMADHAN NUR ZAINAL

NIM : 70200120082

KESEHATAN MASYARAKAT (D)

UIN ALAUDDIN MAKASSAR

\title{
PEMANFAATAN BPJS KESEHATAN PADA LAYANAN KESEHATAN
}

\section{PENDAHULUAN}

Pelayanan kesehatan merupakan salah satu hak dasar masyarakat yang penyelenggaraannya wajib diberikan oleh pemerintah sebagaimana diamanatkan dalam UndangUndang Dasar Negara Republik Indonesia Tahun 1945 Pasal 28 ayat 1: Setiap orang berhak hidup sejahtera lahir dan batin, berhak mendapat hak hidup sehat jasmani dan rohani. tempat tinggal, serta memiliki lingkungan hidup yang baik dan sehat. dan berhak atas pelayanan kesehatan. (Suprianti A, 2017). Pada tanggal 1 Januari 2014, pemerintah Indonesia telah mencanangkan Program Jaminan Kesehatan Nasional yang bertujuan untuk memenuhi jaminan kesehatan universal. (Fadly F, Vianny O. 2019)

Asuransi kesehatan membantu mengurangi resiko orang menanggung biaya kesehatan dari kantong sendiri (keluar dari kantong) dalam jumlah yang sulit diprediksi dan terkadang membutuhkan biaya yang sangat besar. (Suhanda R, 2015). Namun, masih ada permasalahan yang sering muncul yaitu prosedur partisipasi yang sulit dan berbelit-belit. (Witcahyo E, 2016) 


\section{PUSKESMAS}

Puskesmas dalam sistem JKN/ BPJS memiliki peran yang besar kepada peserta BPJS kesehatan. Apabila pelayanan puskesmas yang diberikan baik maka akan semakin banyak peserta BPJS yang memanfaatkan pelayanan kesehatan, namun dapat terjadi sebaliknya jika pelayanan dirasakan kurang memadai (Hasbi 2012).

Banyak faktor yang dapat mempengaruhi individu dalam memanfaatkan pelayanan kesehatan dalam hal ini pemanfaatan puskesmas. Andersen (1968) dalam Indryani (2013) telah menggolongkan beberapa model dalam pemanfaatan pelayanan kesehatan, diantaranya terdapat model demografi dan struktur sosial. Penelitian yang dilakukan Logen, Balqis, Darmawansyah (2015) mendapati hasil bahwa variabel umur memiliki hubungan dengan pemanfaatan pelayanan kesehatan. Penelitian Napirah, Rahman dan Tony (2016) memperoleh hasil bahwa terdapat hubungan antara pendidikan dengan pemanfaatan pelayanan kesehatan. Penelitian Hussein, Musiana (2012) menunjukkan bahwa faktor pekerjaan sangat berpengaruh terhadap pemanfaatan pelayanan kesehatan di puskesmas. Masita, Yuniar, Lisnawaty (2015) dalam penelitiannya diperoleh hasil bahwa ada hubungan yang bermakna antara akses dengan pemanfaatan pelayanan kesehatan. (Londo, J, dkk, 2017)

\section{BEBAN KERJA}

Analisis beban kerja adalah upaya menghitung beban kerja pada satuan kerja dengan cara menjumlah semua beban kerja dan selanjutnya membagi dengan kapasitas kerja perorangan persatuan waktu. Kepmenkes RI No. 81/Menkes/SK/I/2004 tentang Pedoman Penyusunan Perencanaan Sumber Daya Manusia Kesehatan Di Tingkat Propinsi, Kabupaten/Kota serta rumah sakit merupakan pedoman yang digunakan untuk penyusunan rencana penyediaan dan kebutuhan 
SDM di institusi pelayanan kesehatan. Pedoman tersebut menggunakan metode WISN (Workload Indicators of Staffing Need), metode ini adalah indikator yang menunjukkan besarnya kebutuhan tenaga pada sarana kesehatan berdasarkan beban kerja, sehingga lokasi/relokasi akan lebih mudah dan rasional. (S Alam, dkk, 2018)

Permasalahan klasik yang sering timbul di Puskesmas adalah berupa ketersediaan tenaga kesehatan yang kurang serta kelengkapan obat yang belum memadai, ditambahkan pula dengan sikap dan perilaku petugas kesehatan terhadap pasien. Terkadang hubungan antara petugas kesehatan dengan pasien belum tercipta secara baik menimbulkan rendahnya tingkat kepercayaan terhadap layanan yang diberikan. Hal tersebut banyak mempengaruhi minat masyarakat khususnya peserta BPJS kesehatan untuk memperoleh pelayanan kesehatan di Puskesmas (Alamsyah,2011).

Hasil penelitian yang dilakukan oleh Syamsul Alam, Sitti Raodha, dan Surahmawati tentang analisis perhitungan kebutuhan tenaga paramedic pada Poliklinik Ass-Syifaa UIN Alauddin Makassar menggunakan metode WISN maka diperoleh waktu kerja tersedia tenaga medis, standar beban kerja, standar kelonggaran, dan Kebutuhan tenaga SDM. (S Alam, dkk, 2018) 


\section{DAFTAR PUSTAKA}

Suprianto, A., \& Mutiarin, D. (2017). Evaluasi Pelaksanaan Jaminan Kesehatan Nasional. Journal of Governance and Public Policy, 4(1), 71-107.

Fadly, F., \& Vianny, O. (2019). Pemanfaatan Jaminan Kesehatan Nasional (JKN) Tahun 2018 di Provinsi Riau. Jurnal Kebijakan Kesehatan Indonesia: JKKI, 8(4), 164-167.

Suhanda, R. (2015). Jaminan Kesehatan Dan Managed Care. Jurnal Kedokteran Syiah Kuala, 15(2), 104-113.

Witcahyo, E. (2016). Kesiapan dan Persepsi Masyarakat Kabupaten Bondowoso terhadap Kebijakan Jaminan Kesehatan Nasional (JKN)(Preparedness and Perception of Bondowoso Community for National Health Insurance). Pustaka Kesehatan, 4(1), 188-195.

Hasbi, F. H. (2012). Analisis hubungan persepsi pasien tentang mutu pelayanan dengan pemanfaatan ulang pelayanan rawat jalan puskesmas poncol Kota semarang tahun 2012. Jurnal Kesehatan Masyarakat Universitas Diponegoro, 1(2), 18776.

Londo, J. P., Tucunan, A. A., \& Maramis, F. R. (2017). Hubungan antara Karakteristik Peserta BPJS Kesehatan dengan Pemanfaatan Pelayanan Puskesmas di Wilayah Kerja Puskesmas Tahuna Barat. KESMAS, 6(3). 
Alam, S., Raodhah, S., \& Surahmawati, S. (2018). Analisis Kebutuhan Tenaga Kesehatan (Paramedis) Berdasarkan Beban Kerja Dengan Menggunakan Metode Workload Indicator Staffing Needs (WISN) di Poliklinik Ass-Syifah UIN Alauddin Makassar. Al-sihah: The Public Health Science Journal, 10(2).

Alamsyah, D. (2011). Manajemen pelayanan kesehatan. Yogyakarta: Nuha Medika. 